\title{
CORPORATE SOCIAL RESPONSIBILITY REPORTING: DOES WRITING STYLE MATTER?
}

\author{
Dr. Maretno Agus Harjoto \\ Professor of Finance \\ Graziadio Business School \\ Pepperdine University Malibu, California, USA \\ E-mail: maretno.harjoto@ pepperdine.edu \\ Dr. Jadallah Jadallah \\ Assistant Professor of Accounting \\ Scott L. Carmona College of Business \\ Saginaw Valley State University, University Center, Michigan, USA \\ E-mail: jjadalla@svsu.edu \\ Dr. Indrarini Laksmana \\ Professor of Accounting \\ College of Business Administration \\ Kent State University Kent, Ohio, USA \\ E-mail: ilaksman@kent.edu \\ Dr. W. Eric Lee \\ Associate Professor of Accounting and Accounting Alumni Faculty Fellow \\ College of Business Administration \\ University of Northern Iowa, Cedar Falls, Iowa, USA \\ E-mail: eric.lee@uni.edu
}

\begin{abstract}
This study offers an extension of Harjoto, Laksmana and Lee (2020) by presenting a descriptive comparison of gender differences in writing style, and how they impact the choice of words and the readability of corporate social responsibility (CSR) reports. We examine readability, solidarity, and certainty of CSR reports. We find that female CSR leaders use a writing style that conveys greater solidarity with their audience, thereby making a better connection with the stakeholders. These CSR reports are also more readable than those written by their male counterparts. The attributes of readability and solidarity, but not certainty, are in turn positively related to future CSR performance. In comparison, for CSR reports issued by male signers, we find a writing style that conveys greater certainty, which is in turn positively associated with the firms' future financial performance. Overall, findings show that writing style of CSR reports is an important issue for both firms and investors to consider.
\end{abstract}

Keywords: Female Leadership, CSR Report, Readability, Solidarity, Certainty, CSR Performance.

JEL Classification Codes: M4, Q5, Z1. 


\section{INTRODUCTION}

As we are going through the COVID-19 pandemic, Black Rock, Inc. (the world's largest asset management company), in its 2021 Investment Stewardship Report, indicates a shift toward greater climate-related considerations in guiding their investment decisions, as "investors and others will be looking to see how companies are rebuilding their businesses for long-term sustainability and value creation" (Black Rock, 2020, p. 21). This happens at a time when the Biden administration is also directing the U.S. Department of Labor to ease the way for fund management and advisory firms to consider environmental, social, and governance (ESG) outcomes when selecting possible investment channels (Bloomberg, January 20, 2021). With the increasing importance of corporate social responsibility (CSR) reporting, investors should become better informed of what and how the content of CSR reports could impact their investment portfolios. Beyond the perfunctory roles of maintaining reputation with key stakeholders and complying with regulatory requirements, the CSR reports look increasingly likely to become an indispensable compass to help investors navigate their own investments. This paper thus looks at how investors could potentially leverage the findings regarding writing style difference between genders when utilizing CSR reports.

In a paper by Harjoto, Laksmana and Lee (2020), they examine gender differences in writing style and how they affect the selection of words and the readability of CSR reports. A few word-choice issues were examined. First, the paper examines whether women are more likely than men to use words that emphasize others than themselves (i.e., greater use of second- and third-person pronouns than first-person pronouns), which would build stronger connections, hence showing greater solidarity with readers. Second, the paper examines whether women are less assertive than men when it comes to using hedges or tentative words (e.g., maybe, almost, perhaps, somewhat) as compared to words expressing certainty (e.g., precisely, absolutely, always, never) in their writing. Third, the study measures the readability of the reports using two widely used metrics, Simple Measure of Gobbledygook (SMOG) (McLaughlin 1969) and Fog (Gunning 1952) indexes. These indexes use formulas that incorporate number of complex words, words per sentence and complex sentences. From there, the study examines whether differences in word selection patterns and readability are associated with firms' future financial and social performance. In this study, we provide an extension of Harjoto, Laksmana and Lee (2020) by providing a descriptive comparison to further illustrate gender differences in writing style, and how they affect the selection of words and the readability of CSR reports.

Table 1. Samples of Opening Statements in CSR Reports

\begin{tabular}{|l|l|l|}
\hline Companies & Female Signers & Male Signers \\
\hline Verizon & In 2014, six 12-year-old girls from & I am pleased to share Verizon's \\
& Resaca Middle School in Los & 2007 Corporate Responsibility \\
& Fresnos, Texas, won Best in Nation & Report, "Doing the Work." In these \\
in the Verizon Innovative App & pages, we highlight our \\
Challenge. The girls invented an app & accomplishments and challenges in \\
called "Hello Navi" to help a visually & the areas that define our approach \\
impaired classmate better navigate & to corporate responsibility, as well \\
the halls of their school. Their & as provide an in-depth look at a few \\
& success took them all the way to the & of our signature programs. We hope \\
& White House Science Fair in & this gives you a feel for the human \\
& Washington, DC, hosted by President & impact of these initiatives and, \\
& Barack Obama. The President stated & together with our previous three \\
\hline
\end{tabular}




\begin{tabular}{|c|c|c|}
\hline & $\begin{array}{l}\text { that "Not only do these young ladies } \\
\text { have big brains," said the President, } \\
\text { "but they also have big hearts." The } \\
\text { President was so right. Source: } 2014 \\
\text { Verizon Corporate Responsibility } \\
\text { Report - signed by Rose Stuckey } \\
\text { Kirk (Verizon, 2014). }\end{array}$ & $\begin{array}{l}\text { reports, demonstrates a consistent } \\
\text { record of achievement in corporate } \\
\text { responsibility. Source: } 2007 \\
\text { Verizon Corporate Responsibility } \\
\text { Report - signed by Ivan Seidenberg } \\
\text { (Verizon, 2007). }\end{array}$ \\
\hline $\begin{array}{l}\text { PepsiCo and } \\
\text { Coca Cola } \\
\text { Enterprises } \\
(\mathrm{CCE})\end{array}$ & $\begin{array}{l}\text { Every day, PepsiCo earns its license } \\
\text { to operate in the thousands of } \\
\text { communities we serve. As one of the } \\
\text { world's largest food and beverage } \\
\text { companies, we have some distinct } \\
\text { responsibilities. We have a } \\
\text { responsibility to support economic } \\
\text { development, to improve our } \\
\text { environmental footprint and to help } \\
\text { work toward solutions to issues such } \\
\text { as obesity and undernourishment. } \\
\text { Source: PepsiCo Corporate } \\
\text { Citizenship Report - signed by Indra } \\
\text { K. Nooyi (PepsiCo, 2008). }\end{array}$ & $\begin{array}{l}\text { At CCE (Coca Cola Enterprises), } \\
\text { we have committed to taking a } \\
\text { broader view and considering the } \\
\text { most significant impacts of our } \\
\text { value chain, as outlined in our } \\
\text { sustainability plan. To this end, } \\
\text { where stated, our value chain data } \\
\text { goes beyond our own operations. } \\
\text { Source: Coca Cola Enterprises } \\
\text { Corporate Responsibility \& } \\
\text { Sustainability Report - signed by } \\
\text { John F. Brock and Hubert Patricot } \\
\text { (Coca Cola Enterprises, 2014). }\end{array}$ \\
\hline IBM & $\begin{array}{l}\text { We are witnessing a historic } \\
\text { convergence of global shifts - the } \\
\text { phenomena known as Big Data, cloud } \\
\text { computing, mobility, and social } \\
\text { business. Any one of these would } \\
\text { have been disruptive for technology } \\
\text { and business. Together, they promise } \\
\text { to transform global society. So the } \\
\text { question facing every enterprise and } \\
\text { institution is: What will we make of } \\
\text { this moment? How will we capture } \\
\text { the potential of a planet alive with } \\
\text { data? How will we make use of } \\
\text { powerful business and technology } \\
\text { services available on demand, in the } \\
\text { cloud? What will we create from, and } \\
\text { with, growing networks of } \\
\text { consumers, workers, students, } \\
\text { patients, and citizens? How will we } \\
\text { tap an emerging global culture } \\
\text { defined by people determined to } \\
\text { change the practices of business and } \\
\text { society? To answer these questions, } \\
\text { IBM is executing a bold agenda, } \\
\text { which is reshaping our company for } \\
\text { the next decade and beyond. It } \\
\text { encompasses-indeed, integrates- } \\
\text { our business and citizenship } \\
\text { strategies. Source: } 2013 \text { IBM CSR }\end{array}$ & $\begin{array}{l}\text { IBM has had company-wide } \\
\text { environmental programs for over } \\
45 \text { years and our commitment to } \\
\text { environmental leadership was } \\
\text { formalized in a corporate policy on } \\
\text { environmental protection in } 1971 . \\
\text { Along with IBM's business, our } \\
\text { environmental programs and policy } \\
\text { have evolved over the past four- } \\
\text { plus decades. From their original } \\
\text { focus on the environmental } \\
\text { performance of our manufacturing } \\
\text { operations, we expanded them } \\
\text { significantly over the years to cover } \\
\text { the diverse ways in which IBM } \\
\text { intersects with environmental topics } \\
\text { - from our research, product design } \\
\text { and supply chain to the } \\
\text { environmental benefits derived } \\
\text { from our services and solutions. } \\
\text { This is our 23rd consecutive annual } \\
\text { 'IBM and the Environment' Report } \\
\text { and I am pleased to highlight that } \\
2012 \text { was another year of } \\
\text { environmental accomplishment } \\
\text { across our business. Source: } 2012 \\
\text { IBM CSR Report - signed by } \\
\text { Wayne S. Balta (IBM, 2012) }\end{array}$ \\
\hline
\end{tabular}




\section{Report - signed by Virginia $\mathrm{M}$.}

Rometty (IBM, 2013).

\section{RELATED STUDIES AND ANECDOTAL EVIDENCE}

Several theoretical underpinnings on gender role in leadership and communication styles were adopted in formulating the hypotheses and research questions for the above-mentioned study. Research has shown that male leaders are generally more transactional and more likely to adopt an autocratic or directive lifestyle as shown in Verizon's report by Mr. Seidenberg shown in Table 1. On the other hand, female leaders are generally seen as more relationshiporiented and more transformational. The latter are also more likely to adopt a participative leadership style as shown in Verizon's report by Ms. Kirk.

The social role theory by Eagly (1987) explains the traditional division of labor between men and women where males are seen as breadwinners and females as homemakers. This set of people's expectations and beliefs results in gender stereotyping. The theory extends to explain gender differences in communication style. Following the traditional gender role, women tend to use communication to enhance their social relationships and connections, while men use it for social dominance as shown in the reports by Mr. Brock and Mr. Patricot for Coca Cola as shown in Table 1. The ethics of care theory introduced by Gilligan (1982) also suggest that women naturally have a greater sense of virtuous responsibility and moral interdependency than men. This emphasizes women's general view of the world in terms of interpersonal connections and social responsibility as shown in Ms. Nooyi's report for PepsiCo.

These studies, along with research in communication, are consistent with patterns observed by researchers in regard to female writing. Women writers in general seek to establish a more personal connection with others by using more second- and third-person pronouns versus male writers who have the tendency to use generic first-person pronouns. With emphasis on maintaining a relationship with the audience, women writing style is also less assertive while male writing style emphasizes more certainty. This contrasting difference is shown in the report by Ms. Rometty compared to the report by Mr. Balta for IBM as indicated in Table 1.

Table 2. Comparison between Mr. Wayne S. Balta and Ms. Virginia Rometty

\begin{tabular}{|l|l|l|}
\hline Signer & Mr. Balta & Ms.Rometty \\
\hline SOLIDARITY & 0.85 & 0.94 \\
\hline SELF-REFERENCE & 4.01 & 2.76 \\
\hline OPTIMISM & 54.91 & 52.07 \\
\hline CERTAINTY & 1.75 & 0.93 \\
\hline TENTATIVE & 0.38 & 1.33 \\
\hline Word Counts & 523 & 750 \\
\hline Words per Sentence & 26.15 & 18.75 \\
\hline SMOG & 14.1 & 11.1 \\
\hline FOG & 18.8 & 14.6 \\
\hline CSR Performance & 8 & 12 \\
\hline Financial Performance: & & \\
Tobin's Q & 2.07 & 1.88 \\
Stock Returns & $2.2 \%$ & $2 \%$ \\
\hline
\end{tabular}

Note: This table is constructed based on the CSR Reports' Opening Statements by Mr. Wayne S. Balta (IBM, 2012) and that by Ms. Virginia Rometty (IBM, 2013). 
CSR performance (from the KLD database) and financial performance (from Compustat and CRSP) are calculated one year after the CSR report is issued.

\section{TESTING OUT THE HYPOTHESES}

We provide further investigation of gender differences in writing style and how they affect the selection of words and the readability of CSR reports by examining the opening statements from the IBM CSR reports during 2012 and 2013. CSR reports were downloaded from the Corporate Register database and company websites. Two computerized text analysis software, Linguistic Inquiry and Word Count (LIWC) 2015 and DICTION 6.0, were utilized to measure the two word-choice patterns, solidarity and certainty, as well as readability of the reports. The analysis manually examined whether the person signing or co-signing the CSR report is male or female, and used the gender of the signers to identify the presence of female leadership in CSR reporting.

Three textual attributes were examined: solidarity, certainty and readability of CSR reports. The results on Table 2 show that the opening statement of the 2013 IBM CSR report signed by Ms. Rometty has a greater number of solidarity words and fewer first-person (self) reference words than the opening statement of the 2012 IBM CSR report signed by Mr. Balta. This indicates that female CSR leaders adopt a writing style that expresses greater solidarity with their audience, thereby more likely to make a better connection with the stakeholders.

Table 2 also shows that the 2013 IBM CSR report signed by Ms. Rometty has fewer optimism and certainty words and more words indicating hedges or tentativeness than the opening statement of the 2012 IBM CSR report signed by Mr. Balta. It is interesting to note that Ms. Rometty's opening statement uses fewer words demonstrating certainty and fewer words conveying accomplishments or some level of optimism. Additionally, the opening statement of the CSR report written and/or signed by Ms. Rometty was found to be longer and use shorter words per sentence and therefore indicate that the opening statement written and/or signed by Ms. Rometty is more readable (easier to read) than the CSR report written by Mr. Balta.

Finally, readability and solidarity words, but not certainty words, are positively associated with future corporate social responsibility (CSR) performance, measured using CSR scores from both MSCI ESG Stats and the one-year-ahead ESG total scores compiled by the Bloomberg ESG. CSR scores measure how well companies have incorporated social responsibility principles into their businesses. The data to construct CSR scores were collected from surveys, corporate reports, media reports, regulatory filings and other sources. Table 2 shows that the IBM CSR performance during one year after the CSR report is issued and signed by Ms. Rometty is significantly higher than the IBM CSR performance during one year after the CSR report is issued and signed by Mr. Balta. This implies that firms issuing CSR reports that are more readable and show greater connection with their audience have higher future CSR performance. Meanwhile, for CSR reports issued by male signers, we find a writing style that conveys greater certainty, which is in turn positively associated with the firms' future financial performance. The future financial performance is measured using both one-year-ahead Tobin's Q and one-year-ahead stock return.

\section{CONCLUSION AND IMPLICATION}

Based on evidence presented in Tables 1 and 2 and an extensive empirical study by Harjoto, Laksmana and Lee (2020), we conclude that, with respect to firms' CSR reporting, the writing styles conveyed by signers of either gender matter. Solidarity builds an important connection between a company and its stakeholders. Readability is essential in a firm's goal of getting a message across. Certainty conveys a level of confidence in the outlook of the firms' CSR standing, which is in turn positively associated with investors' assessment of 
firms' future financial performance. While CSR reports published by female signers express greater solidarity and are more readable than reports issued by their male counterparts, CSR reports released by male signers show greater certainty. As CSR reports are used by a broad spectrum of stakeholders such as investors, customers, suppliers, employees, regulatory bodies and the community, users should take heed of our findings to note the potential outcomes that may be attributed to the gender of the report signers. As one remains cognizant of firms' future financial performance, firms seeking to improve their social performance should also make better connection with their key stakeholders and present their accomplishments and social commitments clearly in CSR reports. As the findings showed, having female representation in corporate social responsibility and sustainability teams could overall help to further engender the sense of virtuous responsibility in CSR reports and to connect efficaciously with firms' intended audience.

\section{REFERENCES}

Black Rock. (2020). Our 2021 stewardship expectations: Global principles and market-level voting guidelines. New York, New York, USA. Retrieved January 7, 2021, fromhttps://www.blackrock.com/corporate/literature/publication/our-2021stewardship-expectations.pdf

Bloomberg. (January 20,2021). Biden administration considers reversing Trump's ESG rule change. Retrieved January 20, 2021, from https://www.bloomberg.com/news/articles/2021-01-20/biden-administrationconsiders-reversing-trump-s-esg-rule-change

Coca Cola Enterprises. (2014). Innovating for a Sustainable Future: Our journey in 2013. Corporate Responsibility \& Sustainability Report 2013/2014. Atlanta, Georgia, USA. Retrieved January 6, 2021, from https://demo.wikirate.org/files/ 176099/241192.pdf

Eagly, A. H. (1987). Sex Differences in Social Behavior: A Social-Role Interpretation. Hillsdale, NJ: Erlbaum.

Gilligan, C. (1982). In a Different Voice. Cambridge, MA: Harvard University Press.

Gunning, R. (1952). The Technique of Clear Writing. New York, NY: McGraw-Hill.

Harjoto, M. A., Laksmana, I., \& Lee, W. E. (2020). Female leadership in corporate social responsibility reporting: Effects on writing, readability and future social performance. Advances in Accounting, 49, 1-14.

IBM. (2012). 2012 Corporate Responsibility Report. Armonk, New York, USA. Retrieved January 6, 2021, from https://www.ibm.com/ibm/responsibility/2012/overview/yearin-review.html

IBM. (2013). 2013 Corporate Responsibility Report. Armonk, New York, USA. Retrieved January 6, 2021, from https://www.ibm.com/ibm/responsibility/2013/

McLaughlin, G. (1969). SMOG grading: A new readability formula. Journal of Reading, 12, 639-646. 
PepsiCo. (2008). 2008 Corporate Citizenship Report. Purchase, New York, USA. Retrieved January 6, 2021, from https://pepsico.mediaroom.com/index.php?s=43\&item=218

Verizon. (2014). 2014 Corporate Responsibility Supplement. New York, New York, USA. Retrieved January 6, 2021, from https://www.verizon.com/about/sites/default/files/2014_Verizon_Corporate_Social_ Responsibility_Report.pdf

Verizon. (2007). Doing the work. 2007 Verizon Corporate Responsibility Report. New York, New York, USA. Retrieved January 6, 2021, from https://www.verizon.com/about/sites/default/files/2007-verizon-corporateresponsibility-supplement.pdf

\section{Copyrights}

Copyright for this article is retained by the author(s), with first publication rights granted to the journal. This is an open-access article distributed under the terms and conditions of the Creative Commons Attribution license (http://creativecommons.org/licenses/by/4.0/) 